\title{
IMPROVEMENT OF MOTIVATION WITH LEADERSHIP AND WORK ENVIRONMENT AND THE IMPACT OF WORK SATISFACTION
}

\author{
Ida Ayu Oka Martini \\ Universitas Pendidikan Nasional, Denpasar \\ email: dayuokamartini@undiknas.ac.id,
}

\begin{abstract}
This research was conducted to analyze the role of leadership, work environment, and work motivation in increasing satisfaction a nurse's job at the Ganesha General Hospital. The number of nurses in the hospital was 135 . Data collection was carried out by distributing questionnaires to research respondents namely all nurses totalling 35 nurses so that it included the saturated sample method. Data analysis techniques were performed using path analysis, hypothesis testing was performed at a significance level of 5 per cent. Data processing is done using computer applications. The results showed that work motivation, leadership and work environment were positively significantly able to increase nurse job satisfaction. Work motivation acts as a partial mediator in the relationship of leadership to job satisfaction and works environment to job satisfaction.
\end{abstract}

Keywords: leadership, work motivation, work environment, job satisfaction

\section{Introduction}

In the current era of globalization, every company must be able. The company must be able to coordinate all functions of the company properly so that the company's activities can run smoothly, which will have an impact on the job satisfaction of its employees. The low job satisfaction of employees in a company can cause various negative impacts such as absenteeism, strikes, change of work, and intentional damage. Conversely, employees with high levels of job satisfaction will be able to overcome this because they have the responsibility and commitment to advance the company. Employees who are more satisfied tend to be more effective so they can increase company productivity. Research on job satisfaction is becoming increasingly important in companies because it is believed that high job satisfaction will encourage increased individual and group performance that will increase total organizational effectiveness.

One of the factors that influence employee job satisfaction is leadership, (Wehelmina Rumawas, 2015). Leadership is the main key in management which plays an important and strategic role for the survival of a company. A leader must be able to motivate and create social conditions that benefit each employee so that employee job satisfaction is achieved which has implications for increasing employee work productivity. In contrast to the findings of Laksmi et al (2014) states that the leadership variable does not have a significant effect on employee job satisfaction

Another factor influencing employee job satisfaction in carrying out tasks is the work environment ie everything around workers that can affect themselves in carrying out tasks ( Nitisemito, 2015). An unsatisfactory work environment can reduce work morale. Quinerita's research (2015) states that the work environment is a variable that significantly influences employee job satisfaction. The findings of different research results obtained from the results of research by Dhermawan 
(2012) which states that the work environment variable does not significantly influence job satisfaction.

Job satisfaction is not only influenced by leadership and work environment variables, but motivation is something that needs to be considered by company management. Sulistiyani's research results, (2014) showed that employee motivation indicated by the support of activities affected employee job satisfaction. The findings differ from Dhermawan's (2012) study which states that motivational variables do not significantly influence job satisfaction.

Ganesha General Hospital is a Type C Private Hospital and is under the auspices of the Ganesha Foundation, so this is what makes Ganesha Hospital different from Government Hospitals both in terms of employee recruitment systems to the management of its service activities, ranging from administrative services, medical record services, medical support services, medical services, nursing services and others.

During its development, the Ganesha General Hospital showed a fluctuating number of visits and a downward trend. Indications of the decline in visits can be caused by the lack of promptness of nurses 'services to patients which may result from nurses' dissatisfaction at work.

Based on the phenomena and research gap stated above, this study aims to uncover increased motivation with leadership and work environment and their impact on job satisfaction employees, in particular, nurses at the Ganesha Gianyar General Hospital.

\section{Literature Review, Previous Research Results, and Research Hypotheses Job Satisfaction}

According to Robbins (2015) job satisfaction is a general attitude towards one's work, where there is a difference between the amount of rewards workers receive and the amount they believe they should. Various studies have proven that if in his work, someone has the autonomy to act, make important contributions to the organization and employees get feedback about the results of the work they do, then that person will feel satisfied. Handoko (2016) suggests that job satisfaction is a pleasant or unpleasant emotional state, with which employees view their work. Meanwhile, according to Hasibuan (2016) job satisfaction is a pleasant emotional attitude and loves his job. Another opinion from Martoyo (2014) regarding the notion of job satisfaction is the emotional state of employees where there is an intersection between the value of service that is desired by the employee concerned.

Based on the above understanding, it can be concluded that job satisfaction is a pleasant or unpleasant emotional attitude from employees towards their work when compared to the rewards they should receive following their expectations.

Satisfaction can be influenced by several factors, including work motivation (Husaini, 2017, Widya Paramita, 2015), Leadership (Idrus Sikku (2017, Suspa Hariati (2015), and work environment (Corry Yohana (2017, Rasmuji (2017).

\section{Motivation}

Motivation has an important role in everyday human life because motivation 
is a motivating factor for human behaviour. Understanding motivation is a psychological process that reflects the interaction between attitudes, perceptual needs and decisions that occur in a

person. According to Martoyo (2014), Motivation is a mental condition that encourages action and gives strength that leads to the achievement of needs, gives satisfaction or reduces imbalances. "Based on the opinion of experts, it can be concluded that motivation is the basic impulse that drives people to behave. This impetus is on someone who moves to do something yes following the urge in him.

Husaini's research (2017) states that work motivation has a positive and significant effect on job satisfaction in Banjarbaru Hospital. Similar results obtained in the study of Widya Paramita (2015) states that employees who have high work motivation also have high job satisfaction at PT. Pos Indonesia (Persero) Bekasi. Relevant research was also shown in Sidik Priandana's (2015) study that motivation had a positive and significant effect on job satisfaction of West Java Provincial Mining and Energy employees.

Hypothesis 1: Work motivation has a positive effect on job satisfaction.

\section{Leadership}

Leadership is a complex person's effort to influence others to achieve a task, mission, or suggestion, and the goal of achieving organizational goals in a way that makes it more cohesive and makes more sense. According to Hasibuan (2016) states that "Leadership is a way or style of a leader influencing the behaviour of subordinates, so they want to work productively to achieve organizational goals". Fahmi (2015) said that "Leadership is a science that comprehensively studies on how to direct, influence, and supervise others to carry out tasks by planned orders". From the opinions of the experts above it can be concluded that leadership is the art of ability that influences human behaviour and controls, directs, and supervises people in the organization so that their behaviour matches the behaviour desired by the leader.

Research conducted by Idrus Sikku (2017) states that leadership dimensions significantly influence employee job satisfaction of PT. Nippon Indosari Corporindo Tbk. In his research confirmed that leaders who successfully apply the leadership dimension can create job satisfaction for subordinates. Suspa Hariati's research (2015) states that leadership has a positive and significant effect on employee job satisfaction at Darul 'Ulum Jombang Islamic Boarding School. A similar study was conducted by Dwiki Ananto Yudo (2015) entitled the effect of leadership on job satisfaction of permanent lecturers at a private tertiary institution in DKI Jakarta.

Hypothesis 2: Leadership has a positive effect on job satisfaction

Tri Fitriani's (2016) research results state that leadership has a positive and significant effect on employee work motivation at the Selayar Islands Regency community empowerment agency. A similar result shown by Anum Reknowati 
Ningsih (2016) states that leadership has a positive and significant effect on employee motivation in PDAM Madiun. Rizky Natassia (2016) in his research stated that leadership and work motivation on the performance of employees of the Padang statistical centre (BPS). Intan Ayu (2018) states that leadership style has a significant effect on auditor motivation on auditors of public accounting firms in Central Jakarta.

Hypothesis 3: Leadership has a positive effect on work motivation.

\section{Understanding the Work Environment}

According to Nitisemito (2015), the work environment is everything in the room around the worker that can significantly affect him in carrying out the assigned tasks. For example colouring, cleanliness, air exchange, lighting, music, security, and noise. In general, the work environment within a company is an environment where the employees carry out their duties and work daily. Based on the above opinion it can be concluded that the work environment is anything that can affect him in carrying out his duties and work.

In a Corry Yohana (2017) study, a conducive work environment can provide job satisfaction for employees at BNI Life insurance Jakarta. In his research, the work environment has a positive and significant effect on job satisfaction. Rasmuji (2017) mentioned in his research the work environment had a positive and significant effect on job satisfaction among PD BPR employees, BKK Batang. Zulfahmi's research (2017) mentions that the work environment has a positive and significant effect on job satisfaction among Perum Perhutani Ngawi employees.

Hypothesis 4: The work environment has a positive effect on job satisfaction.

Research conducted by Maulana, Ferry (2017) found that work environment research has a positive and significant effect on work motivation for employees of PT, Telkom Indonesia, Tbk, Witel Jatim Selatan Malang. Wahyudi (2017) obtained research results that showed that the work environment had a positive and significant effect on work motivation in the civil service police and Wilayatul Hisbah district of Bireuen. Putry Mutiarasari (2017) found that work environment research results had a positive and significant effect on the motivation of $\mathrm{Pg}$ employees, Kebon Agung, Malang Regency.

Hypothesis 5: The work environment has a positive effect on work motivation.

Based on theoretical and empirical studies, where work motivation, leadership, and work environment affect satisfaction, while on the other hand motivation is also influenced by leadership and work environment, the following research hypotheses can be arranged:

Hypothesis 6: Motivation act as remedies on the relationship of leadership on job satisfaction

hypothesis 7: Motivation act as pemediasi the working environment related to 
work satisfaction

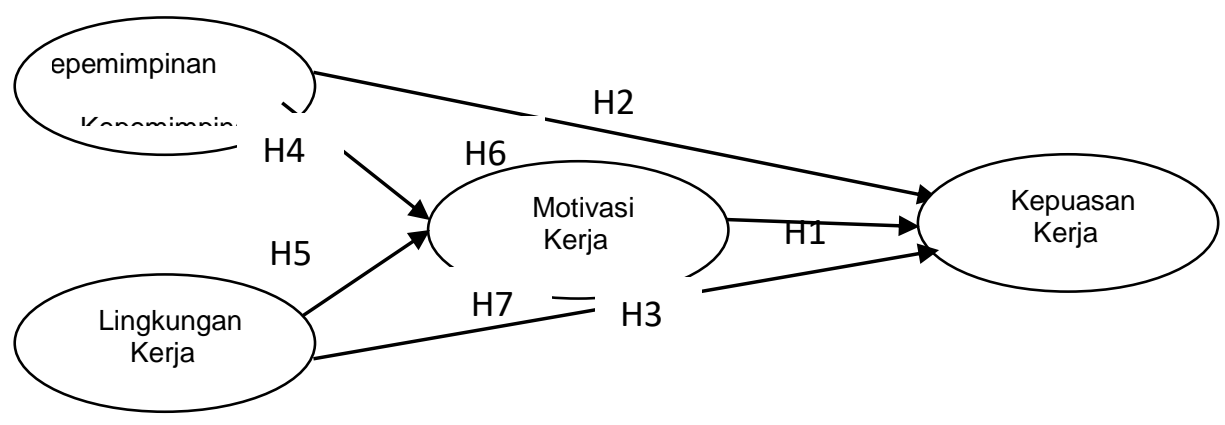

Figure 1. Framework

\section{METHOD}

the number of respondents used in this study was 135 nurses in Gianyar Ganesha Ruah General Hospital, using a saturation sampling method. Data collection was carried out using a questionnaire with semantic differential scales ten-point scale. Hypothesis testing is done at a significance level of 5 per cent, data processing methods are carried out using path analysis, and to show the mediation the Sobel formula is used.

\section{RESULTS}

\section{Evaluation of Goodness Of fit}

Based on the test criteria, Chi-square $\left(\mathrm{x}^{2}\right)$ processing results of Amos for windows version 23 as shown in the picture above, then the following table can be made:

Table 1

Evaluation of Goodness of fit

\begin{tabular}{|c|c|c|c|}
\hline The goodness of fit Index & $\begin{array}{c}\text { Results } \\
\text { Model }\end{array}$ & Sig & Information \\
\hline Chi-square $\left(\mathrm{X}^{2}\right)$ & 10,14 & 0,253 & Good \\
\hline
\end{tabular}

Source: Data processed, 2019

Paying attention to the cut-of-value and Goodness of fit model results in the table above, it looks good criteria so it is feasible to be used for further tests.

\section{Path Analysis}

Referring to the hypothesis, a relationship model between variables such as Figure 1 is developed: 


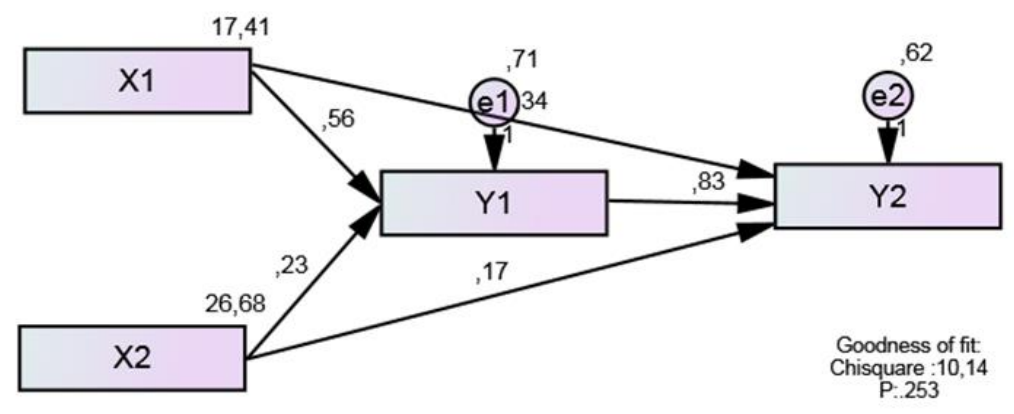

Figure 1: Model of Relationship Between Variables

Based on the picture above, a goodness of fit analysis, structural model analysis can be carried out.

\section{Structural Equation Model Analysis}

Based on the results of the calculation of the regression coefficient (regression weight) which can be seen in the following table:

Tabel 2

Koefisien Regresi

\begin{tabular}{|ccc|cccccc|}
\hline \multicolumn{2}{|c|}{ Hubungan Antar Variabel } & Std. Estimate & Estimate & S.E. & C.R. & P & Keterangan \\
\hline Y1 & $<---$ & X1 & 0,846 & 0,555 &, 017 & 31,878 & $* * *$ & Significance \\
Y1 & $<---$ & X2 & 0,435 & 0,230 &, 014 & 16,377 & $* * *$ & Significance \\
Y2 & $<---$ & X1 & 0,360 & 0,344 &, 048 & 7,216 & $* * *$ & Significance \\
Y2 & $<---$ & Y1 & 0,571 & 0,832 &, 081 & 10,322 & $* * *$ & Significance \\
Y2 & $<---$ & X2 & 0,220 & 0,170 &, 023 & 7,452 & $* * *$ & Significance \\
\hline
\end{tabular}

Source: processed data, 2019

Based on Table 2, leadership (X1), Work environment (X2 ), and work motivation (Y1) have a significant positive effect on job satisfaction (Y). Likewise, leadership (X1), and work environment (X2), have a significant positive effect on work motivation (Y1). This is indicated by the p-value of the effect of each variable is smaller than 0.05 .

\section{Discussion}

\section{The effect of work motivation on job satisfaction}

Based on the results of the study it can be seen that the effect of work motivation on satisfaction job has a standardized estimate (regression weight) of 0.571 with a $\mathrm{Cr}$ of 10.322 on a probability of 0,000 .value Probability $=0,000$ $<0.05$ indicates that the influence of work motivation variables on job satisfaction is significant. Thus the fifth hypothesis is proven true. The results of the study mean that the better the work motivation, the higher the job satisfaction of nurses 
at Ganesha Public Hospital.

Motivation is seen from motivation as a driving force that makes a person have the desire to do the best of what they do. When employee motivation has been fulfilled, job satisfaction will be achieved. As expressed by Van (2015) which states that motivation has the potential to be one of the most important suggestions in shaping job satisfaction. The results of the study are consistent with research Husaini's(2017), Widya Paramita (2015), Sidik Priandana (2015).

\section{Effect of Leadership on Job Satisfaction}

Based on the results of the study showed the influence of leadership variables on satisfaction job has a standardized estimate (regression weight) of 0.360 with a $\mathrm{Cr}$ of 7.216 on a probability of 0,000 . value Probability $=0,000$ $<0.05$ indicates that the influence of leadership variables on job satisfaction is significant. Thus the third hypothesis is proven true. The results of the study give the meaning that the better the leadership that is applied to management, the higher the work motivation of nurses at Ganesha General Hospital

Having leadership skills, having the ability to influence people other or groups of people. A leader is also an active person in making plans, coordinating, and doing work to achieve goals together. When subordinates feel directed by the leadership by the job description by the portion, job satisfaction will be felt by their subordinates. This research is in line with Idrus Sikku (2017), Suspa Hariati (2015) and Dwiki Ananto Yudo (2015).

\section{Effect of Work Environment on Job Satisfaction}

Based on the results of the study, it can be seen that the influence of work environment variables on job satisfaction has a standardized estimate (regression weight) of 0.220 with a $\mathrm{Cr}$ of 7.452 on probability 0.000 . value Probability = $0,000<0.05$ indicates that the influence of work environment variables on job satisfaction is significant. Thus the fourth hypothesis is proven true. The results of the study mean that the better the work environment, the higher the motivation of nurses at Ganesha Hospital.

Job satisfaction appears as a result of the work situation that exists in the company. Job satisfaction reflects the employees' feelings about being happy or not happy, comfortable or uncomfortable with the work environment of the company where he works. Forms of employee job satisfaction will be seen from positive or negative attitudes in employees. Employee job satisfaction is dynamic, meaning that it can change at any time. At one time employees may experience dissatisfaction, but after improvement by company management, employees will be able to become satisfied. The results of the study are in line with research by Corry Yohana (2017), Rasmuji (2017) and Zulfahmi (2017).

\section{The influence of leadership on work motivation}

Based on the results of the study it can be seen that the influence of leadership variables on motivation has a standardized estimate (regression weight) of 0.846 with a $\mathrm{Cr}$ of 31.887 at a probability of 0,000 .value Probability $=$ $0,000<0.05$ indicates that the influence of leadership variables on motivation is 
significant. Thus the first hypothesis is proven true. The results of the study mean that the better the leadership applied by hospital management, the higher the motivation of nurses working at Ganesha Public Hospital. A leader who is successful in leading a company can be seen from the leadership potential and companies that can compete healthily with other companies, and can give effect to the company's image with a positive image. So that the leadership functions that run well can help increase employee motivation. The results of this study were supported by Tri Fitriani (2016), Anum Reknowati Ningsih (2016). Rizky Natassia (2016) and Intan Ayu (2018).

\section{The Influence of Work Environment on Work Motivation}

Based on the research results it is known that the influence of work environment variables on motivation has a standardized estimate (regression weight) of 0.435 with $\mathrm{Cr}$ (equal to 16,377 on probability 0,000 . value Probability $=0,000<0.05$ indicates that the influence of work environment variables on motivation Thus the second hypothesis is proven true. Research results provide meaning that the better the work environment, the higher the work motivation of nurses at Ganesha Public Hospital.

The work environment factor is an important factor in influencing work motivation. The safe, comfortable and conducive work environment will make and enthusiasm employees work to increase so that the jobs that become their duties can be completed properly and on time as expected. Likewise, vice versa work environment that is not safe, uncomfortable, dirty, noisy and bad working relationships it makes employees feel bored, lazy and do not feel at home at work so that the jobs that become their tasks are neglected and not finished properly. Inline research conducted by Moulana, Ferry (2017), Wahyudi (2017) and Putry Mutiarasari (2017).

\section{Effect of Leadership and Kerha Environment on Job Satisfaction through Work Motivation}

Testing The Effect of Mediation Variables Work Motivation in this study uses the concept of Baron \& Kenny (1996) as follows: a) if the effect of the independent variables on mediating variables is significant, the effect of mediating variables on the dependent variable is significant, and the effect of the independent variables on the dependent variable is also significant, then the role of partial mediation occurs. c) if the effect of the independent variable on the mediating variable is significant, the effect of the mediating variable on the dependent variable is significant, and the effect of the independent variable on the dependent variable is not significant, then the full mediation role will occur. c) if the effect of the independent variable on the mediating variable and the effect of the mediating variable on the dependent variable, one or both of them is not significant, then not as a mediation.

Based on Table 2, where all the relationships that occur between the independent variable with the mediating variable and the dependent variable are significant, work motivation (mediating variable) acts as a partial mediator on the relationship between leadership and work environment variables to job 
satisfaction.

\section{Conclusions and Recommendations}

Based on the results of the discussion it can be concluded that leadership, work environment, and work motivation have a significant positive effect on job satisfaction of nurses at Ganesha Hospital in Gianyar. Likewise, Leadership and the work environment have a significant positive effect on nurses' work motivation. Based on these results, work motivation acts as a mediator in the relationship between leadership and work environment to nurse job satisfaction. This implies that an increase in nurse job satisfaction in Ganesha Gianyar Hospital can be done through improving leadership patterns and work environment, and increasing nurse work motivation.

\section{Limitations and Future Research}

Job satisfaction is influenced by very complex factors, but in this case only discussed leadership, work environment, and work motivation. Future studies can be carried out by including several other relevant variables, to provide more perfect results.

\section{REFERENCES}

Anum Reknowati Ningsih. 2016. kepemimpinan berpengaruh positif dan signifikan terhadap motivasi kerja karyawan pada PDAM kota Madiun. Equilibrium: Jurnal Ilmiah Ekonomi dan Pembelajarannya ISSN: 23031565 (printed) , E-ISSN: 2502-1575 (Online), Vol. IV, no 2

Baron and Kanny, 1996. The mediator-mediator variable distinction in social psychological reserarch: Conceptual, strategic, and statistical consederation,, journal of personality and social psichology, vol. 51, no. 6, pp. 1173-1182

Corry Yohana. 2017. Lingkungan kerja yang kondusif dapat memberikan kepuasan kerja bagi karyawan pada BNI Life insurance Jakarta. Jurnal Agora. Vol 5. No.3

Dhermawan. 2012. Pengaruh Motivasi, Lingkungan Kerja, Kompetensi,Dan Kompensasi Terhadap Kepuasan Kerja Dan Kinerja Pegawai Di Lingkungan Kantor Dinas Pekerjaan Umum Provinsi Bali. Jurnal Manajemen, Strategi bisnis dan Kewirausahaan, Vol 6. No.2 Agustus 2012.

Dwiki Ananto Yudo. 2015. Pengaruh kepemimpinan terhadap kepuasan kerja dosen tetap di sebuah perguruan tinggi swasta di DKI Jakarta. Jurnal Manajemen Strategi Bisnis dan kewirausahaan. Vol 7 No. 2. 2015

Fahmi. 2015. Teori dan Teknik Pengambilan Keputusan. Jakarta: Raja Grafindo Persada

Hair, J.F.Jr; R.E. Anderson, RL. Tatham dan W.C. Black, 1995.Multivariate Data Analysis With Readings, Englewood Cliffs, NJ: Prentice Hall Inc.

Hasibuan. 2016. Manajemen Sumber Daya Manusia, PT. Gunung Agung, Jakarta 
Husaini. 2017. Pengaruh motivasi kerja terhadap kepuasan kerja di Pelayanan Kesehatan RSUD Banjarbaru. Jurnal UNIBOS Makasar Vol 5. Maret 2017

Idrus Sikku. 2017. Dimensi kepemimpinan terhadap kepuasan kerja karyawn PT. Nippon Indosari Corporindo Tbk. Jurnal

Intan Ayu. 2018. Pengaruh Gaya kepemimpinan terhadap motivasi auditor pada auditor kantor akuntan publik di Jakarta Pusat. Jurnal Manajemen Strategi Bisnis dan kewirausahaan. Vol 3 No. 4. 2018

Laksmi dkk. 2014. Pengaruh kepemimpinan terhadap kepuasan kerja karyawan CV Surya Raya.Jurnal riset UNIBOS Makasar Vol 3. Maret 2014

Martoyo. 2014. Manajemen Sumber Daya Manusia, Alfabeta, Bandung

Moulana, Ferry. 2017. Pengaruh lingkungan kerja terhadap motivasi kerja pada karyawan PT, Telkom Indonesia, Tbk, Witel Jatim Selatan Malang. Jurnal Manajemen Strategi Bisnis dan kewirausahaan. Vol 6 No. 2. 2017

Nitisemito. 2015. Manajemen Personalia, Ghalia Indonesia, Jakarta.

Putry Mutiarasari. 2017. Pengaruh lingkungan kerja terhadap motivasi karyawan Pg, Kebon Agung Kabupaten Malang. Jurnal Media Ekonomi dan Manajemen, Vol 15. No. 5 Maret 2017

Quinerita. 2015. Pengaruh lingkungan kerja terhadap kepuasan kerja karyawan lapangan departemen Grasberg. Jurnal Modul, Vol 27. N0.2 Tahun 2015

Rasmuji. 2017. Pengaruh lingkungan kerja terhadap kepuasan kerja pada karyawan PD BPR. BKK Batang. Jurnal Media Ekonomi dan Manajemen, Vol 32. No. 2 Juloi 2017

Rizky Natassia. 2016. Pengaruh kepemimpinan dan motivasi kerja terhadap kinerja karyawan badan pusat statistik (bps) kota Padang. Jurnal Manajemen Strategi Bisnis dan kewirausahaan. Vol 3 No. 6. 2016

Sidik Priandana. 2015. Pengaruh motivasi terhadap kepuasan kerja pegawai Dinas Pertambangan dan Energi Provinsi Jawa Barat. Jurnal Manajemen Strategi Bisnis dan kewirausahaan. Vol 3 No. 8. 2014

Sulistiyani. 2014. Kemitraan dan Model-Model Pemberdayaan. Jogjakarta.:Gava Media

Suspa Hariati. 2015. Pengaruh kepemimpinan terhadap kepuasan kerja pegawai pada Universitas Pesantren Tinggi Darul 'Ulum Jombang.

Tri Fitriani. 2016. Pengaruh kepemimpinan terhadap motivasi kerja pegawai pada badan pemberdayaan masyarakat Kabupaten Kepulauan Selayar.

Van. 2015. Pengaruh motivasi terhadap kepuasan kerja. Jurnal Manajemen Strategi Bisnis dan kewirausahaan. Vol 27 No. 2. 2015.

Wehelmina Rumawas. 2015. Pengaruh kemampuan kerja dan motivasi terhadap kepuasan kerja serta implikasinya pada kinerja pegawai dinas pertambangan dan energi provinsi Jawa Barat. Jurnal Ekonomi dan Bisnis \& Enterpreneurship Vol 7. No2 Oktober 2015.

Widya Paramita. 2015. Pengaruh motivasi kerja terhadap kepuasan kerja pada PT. Pos Indonesia (Persero) Bekasi. Jurnal Riset manajemen Sains Indonesia Vol 6. No.1. 2015

Zulfahmi. 2017. Pengaruh lingkungan kerja terhadap kepuasan kerja pada Karyawan Perum Perhutani Ngawi. Jurnal Manajemen Strategi Bisnis dan kewirausahaan. Vol 9 No. 6. 2017 
Zulfahmi. 2017. The influence of the work environment on job satisfaction on employees of Perhutani Ngawi. Journal of Business Strategy Management and entrepreneurship. Vol 9 No. 6. 2017 